\title{
The U.S. High Technology Export Control Towards China
}

\author{
Yang Chunmei a*, Mai Wenyi \\ a Tianjin Polytechnic University. \\ ${ }^{\mathrm{b}}$ Westminster College. \\ *Corresponding author's email address: jane_ycm@126.com
}

\section{A R T I C L E I N F O}

Received: 17-03-2016

Accepted: 12-04-2016

Available online: 26-05-2016

\section{Keywords:}

Export control;Sino-US;

High-tech; Influence.

JEL Classification: F13

\section{A B S T R A C T}

Attracted by the advantage of economic globalization and the huge potential of international market, an increasing number of countries think highly of international trade and treat it as a significant factor to improve GDP. In addition, the booming science and rapid technology development make high-tech products a crucial section to chase profit in international market. However, there do exists restrictions and barriers between China and the United States for various reason. Thus this essay discusses the current status of high-tech products' trade as well as both positive and negative influences on the exporter (the U.S.) and the importer (China), and indicates that these restrictions do creates extra expenditure of industries in China on research and development.

This is an open access article under the terms of the Creative Commons Attribution License 4.0, which allows use, distribution and reproduction in any medium, provided the original work is properly cited.

DOI: http://dx.doi.org/10.18533/job.v1i4.25.

ISSN: 2380-4041 (Print), 2380-405X (Online)

\subsection{Introduction}

The advantage of economic globalization and the huge potential of international market as well as the booming science and rapid technology development make high-tech products a crucial section to chase profit in international market and an effective tool to improve GDP. However, as the top science and technology superpower, the United States arranged a series of restrictions on technology export towards China, which has a broad market and abundant demand. The causes behind the technology export control are diversified and complex. The World-system Theory gives a perfect theoretical explanation to the occurrence and development of this policy. In reality, this policy is a combination product of military, political, and economic factors. Among these factors, military security is always thought to serve as the dominant cause, under which other factors are considered (Niu, 2010). The military causes behind the technology export control policy are combined by two aspects: China's increasing military power (Lawrence, 2012) and the military-to-military relationship between the U.S. and China (globalfirepower. com 2014). The mistrust not only happens in the political fields, but also appears in the economic field. The difference between market economy in the U.S. and government-intervened economy in China causes the mistrust in economic models (Ping, 2011). The restriction on technology exports to China works to control the large amount of advanced technology inflow to China, extend the imitation lag, and maximize the U.S. economic profits (wright.edu).

The current status of three types of high-tech products (munition, dual-use, and commercial commodities): Munitions are products that have a clear military purpose. An export license is needed for the products that are under strict restriction that it is impossible to trade with China, because it is against the U.S. existing "arms embargo" (Hardin and Gao, 2012). Dual-use goods are products that have commercial purpose as well as potential military function. Chemical and biological commodities are typical examples of dual-use goods because of their 
potential end-use in chemical and biological weapons (U.S. Department of Commerce, 2012). Other technical products have only pure commercial value rather than potential military use, and are under relatively looser control.

The influences of trade restrictions on high-tech exports, especially on Dual-use goods, are the emphasis of this paper. Econometrics will be used to reveal the influence of high-tech exports on both the U.S. GDP and the development of the high-tech industry. The last section focuses on the prediction about the high-tech export restrictions. Trade restrictions secure the national technical advantage but damage the commercial profit, so the future of this policy will depend on what the U.S. perceives as its advantages and disadvantages.

\subsection{Dead weight loss in both the U.S. and China}

The dead weight loss theory explains how the inefficient market does harm to the social welfare in the perfect competition market. In the sphere of dual-use commodities, limit on export will have a negative effect on social welfare and cause dead weight loss. Depending on the international trade theory, free trade can maximize the total welfares of both exporter and importer. The sum of producer and consumer surplus can be damaged by any form of trade barrier.

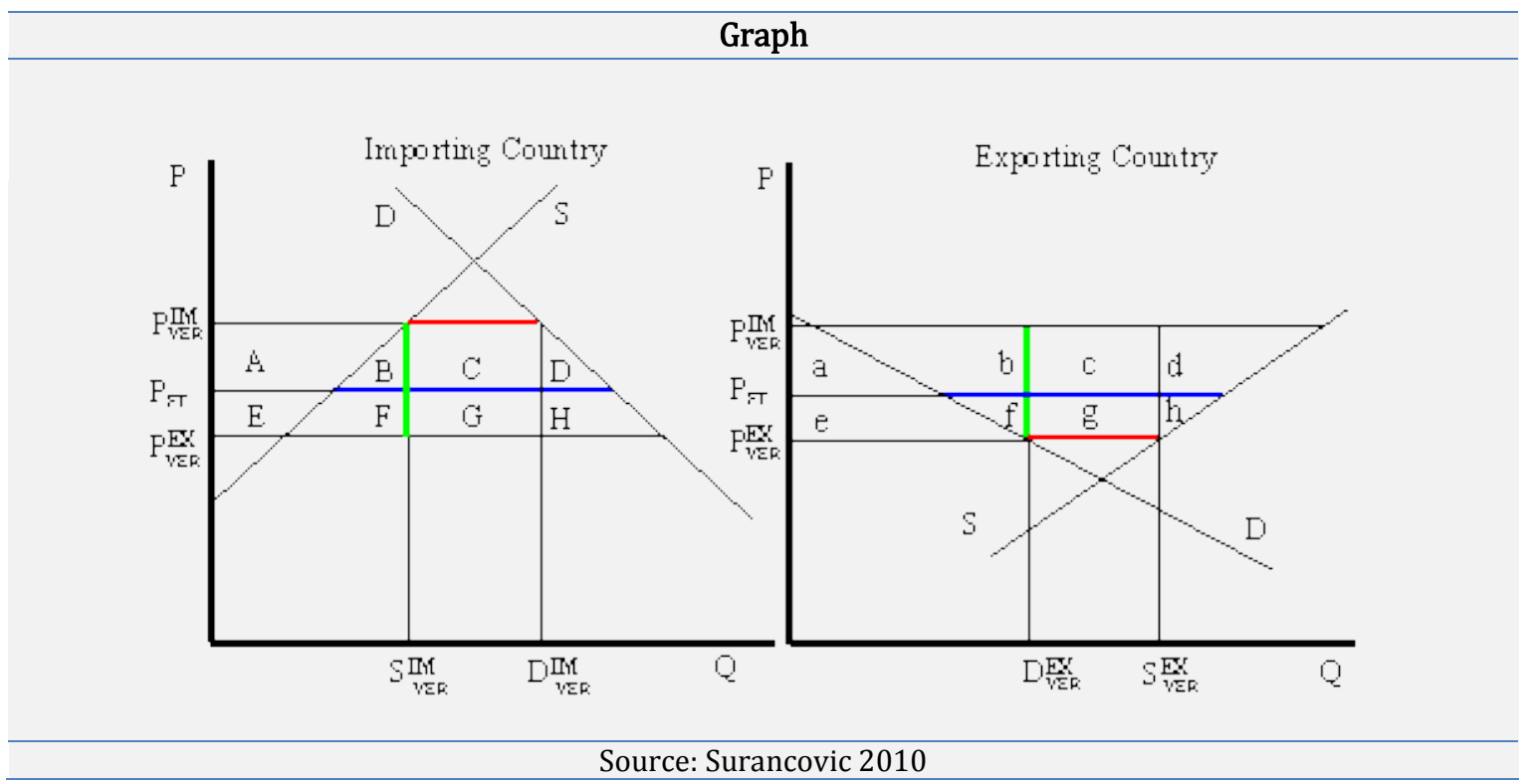

Depending on the graph above, in the international technology commodity market, the U.S. with the comparative technical advantage serves as the exporter, and China serves as the importer. Without export restrictions, free trade would set the equilibrium price at $P_{F T}$, and the amount of technology trade would be represented by the blue line. This equilibrium condition will benefit both the U.S. producers and Chinese consumers. Under this circumstance, Chinese demand of technical commodities can be satisfied, and its social welfare (represented by $A+B+C+D+E+F+G)$ can be fully realized. The same situation happens in the U.S. Its social welfare is also maximized to $\mathrm{a}+\mathrm{b}+\mathrm{c}+\mathrm{d}+\mathrm{e}+\mathrm{f}+\mathrm{g}$. However, with the large number of restrictions the U.S. government set on the technical commodities' export, the price and trade quantity are changed. The volume of technical trade is limited to the red line, $S_{E X}-D_{E X}\left(=D_{I M}-S_{E X}\right)$. This decline in trade volume drives the price of technology goods' in the importing country, China, up to $P_{I M}$, and the prices in the exporting country, the U.S., down to $P_{E X}$. The higher price forced the consumers to pay more on the technical products, reduces the total demand, and causes the dead weight loss $(\mathrm{B}+\mathrm{C}+\mathrm{D}+\mathrm{F}+\mathrm{G}+\mathrm{H})$ in China; the lower price in the U.S. cuts the revenue of technical producers and causes the dead weight loss $(b+c+d+f+g+h)$. This decrease in welfare clearly results from the technology export restrictions. Serving as trade barriers, these restrictions hurt both the total and individual profits of the U.S. and China, change the allocation of two countries' resources, and cause the market inefficiency.

\subsection{Influence on the U.S. GDP}

The econometric method will be used to evaluate the influence of technology export control on the U.S. GDP. As the technology export is not the only factor to determine the GDP, a multi-linear regression will be built in Eviews Program. 
The MLR model:

$G D P$ growth $_{t}=\beta_{0}+\beta_{1} G D P_{t-1}+\beta_{2}$ private consumption $+\beta_{3}$ investm

$+\beta_{4}$ government spending $+\beta_{5}$ technology export $+u$

$\beta_{1}, \beta_{2}, \beta_{3}, \beta_{4}, \beta_{5}$, and $\beta_{6}$ are parameters to evaluate the influence of one unit's change in the independent variables on the dependent variable, the U.S. GDP. With data from http://research.stlouisfed.org/ and http://data.worldbank.org/, the estimations of parameters are below:

$$
\begin{aligned}
\mathrm{GDP} \widehat{\mathrm{Grow}} \mathrm{th}_{t}= & 5.6434-0.0071 \mathrm{GDP}_{t-1}+0.0064 \text { private consumptio }-0.0008 \text { investment } \\
& +0.0049 \text { government expenditur }+0.0514 \text { tech export }
\end{aligned}
$$

The adjusted $R^{2}$ value is 0.8820 . This large value means that $91.01 \%$ of changes in the U.S. GDP growth can be explained by the independent variables, which makes it an excellent model. The P-value of F-stat in this model is 0.0000 meaning that the technology export is a significant factor to determine the US GDP growth.

\subsection{Influence on the U.S. science and technology industry}

In this section, the Eviews will also be used to test the influence of technology exports on the U.S. high-tech industry. MLR model:

Tech industry growth gr $_{t}=\beta_{0}+\beta_{1}$ tech export growth g $_{t}+\beta_{3} R \& D_{t}+\beta_{2}$ GDPgrowth g $_{t}+u$

$\beta_{0}$ : the technology industry growth when all the independent variables are zero.

$\beta_{1}, \beta_{2}, \beta_{3}$ : are partial coefficients, measures the partial effect of individual variables on the dependent variable. With data from http://research.stlouisfed.org/ and http://data.worldbank.org/, the estimations of parameters are below:

Tech $\widehat{\text { industry }}{ }_{t}=-13.029+8.2835$ tech export $_{t-1}+1.6928 G D P_{t}+0.0002 R \& D_{t}$

$R^{2}$ in this model is 0.8655 meaning that $86.55 \%$ changes in the technology industry can be explained by the independent variables in this model. The P-value of F-stat in this model is 0.000112 , which indicates that the technology export is a significant factor to determine the U.S. technology industry.

\subsection{Actual influence on Chinese technology industry}

\section{a. International technology inflow to China}

The technology inflow from the United States was under complex restrictions. However, as the U.S. is not the only technology source for China, limited technical inflow from this scientific and technical superpower does not efficiently hamper the technology development of China. Because it cannot prevent other countries, such as Japan, Korea, and the European Union, from chasing the huge profits in the Chinese technology market. Abundant demand in the China makes it an attractive market for all high-tech exporters, directly induces large amount of high technology inflow, and helps improve China's technical level.

\section{b. Independent research and development of China}

Having realized the difficulty of importing technology products from the Western Countries, China started concentrating on its independent research and development. The percentage of technology expenditure in Chinese GDP keeps increasing, and the average growth rate of Chinese research and development spending is $25.5 \%$. In the year 2012, Chinese expenditure on research and development reached 296.8 billion. China closely followed the U.S. and is the second largest spender on technology. In addition, as a result of the huge population and government support for education and research, China owns the largest number of technical human resources by the year 2009. Substantial investment accelerates the development of Chinese scientific and technological strength.

\subsection{Conclusion}

The restrictions on the high technology exports to China have a long history, during which this policy fluctuated a lot. It is not a temporarily emergent policy, but a product of complicated military, political, and economic factors. The dead weight loss theory shows that restriction on the export of dual-use goods to China will cause losses between both the U.S. and China. Econometric methods statistically show how the high-tech exports to China can improve the U.S. economy. Meanwhile the final part of description on the impacts on Chinese technology industry also indicates that these restriction do creates extra expenditure of industries in China on research and development. 


\section{References}

Co, C. Y. (February 2012) “US Trade in Advanced Technology Products.” Review of Development Economics Issues 1, Vol. 16: 16-30.

Ferguson, I. F., and Kerr, P. K., (2013) The US Export Control System and the President's Reform Initiative. Washington D.C.: Congressional Research Service.

Finance.sina.com.cn, Europe: the Largest Resource of Chinese Technology Inflow, http://finance.sina.com.cn/ roll/20060808/0214843267.shtml (In Chinese).

Globalfirepower.com, The GFP Top10, http://www.globalfirepower.com/

Hardin, D., and Gao, J., (October 2012) “The Export Control Risks of US-China Technology Collaboration.” China Business Review Issues 4, Vol. 39: 35

Hammer, A., Koopman, R., and Martinez A. (October 2009) U.S. Exports of Advanced Technology Products to China. Washington, DC: U.S. International Trade Commission.

Hou, K. (December 2012) "Sino-U.S. Trade Imbalance in the Impact Analysis of U.S. Export Controls," China Market, 49: 43-49. (In Chinese).

Jinyan, W. (May 2012) "Sino-US Technology Trade Analysis.” Jilin University, 1: 174-205. (In Chinese)

Lawrence, S. V., and Macdonald, D., (2012) U.S.-China Relations: Policy Issues. Washington D.C.: Congressional Research Service.

Liang, H. (February 17, 2012) “U.S.-China Technology Export Controls 'Catching' Sino-US Trade Balance.” China Economic Times, 48: A01. (In Chinese).

Niu, X., (February 2010) "Sino-US Relations: Dependence and Fragility." Contemporary International Relations, Vol. 20: 74-95. (In Chinese).

Ping, X., Jian, P., and Limin, Z., (February 2011) "Progress in the Reform of the U.S. Export System." China, 2: 2325. (In Chinese).

Sun, Y. (March 2000) "Researches of Japanese High-tech Export Policy to China." Contemporary International Relationship, No. 3

Suranovic, S. M. (2010) International Trade Theory and Policy. Washington, DC.: Flat World Knowledge.

Wallenstein, M.B. (November 2009) "Losing Controls: How US Export Restrictions Jeopardize National Security and Harm Competitiveness." Foreign Affairs Issues 6, Vol. 88: 11-18.

Wright.edu, The Imitation Lag Hypothesis, http://www.wright.edu/ tdung/product_cycle.htm USCC.gov, U.S.China Economic and Security Review Commission, http://www.uscc.gov/ Annual_Reports/ 2013annual-report-congress.

Xin, L. (May 2011) “Evolution of U.S. Trade Policy and Impact Analysis.” Journal of Hebei University 1: 26-38. (In Chinese).

Yaling, P. (January 2011) “U.S. Policy Toward China in the Economic Nationalism.” Fudan American Review, 1: $36-$ 52. (In Chinese).

Zhou, S. (February 27, 2012) “China-U.S. Economic Relations: Accords and Discords.” China Today. 